\title{
PROSPECTIVE PHARMACOLOGICAL EFFECTS OF PSORALEN PHOTOXIDATION PRODUCTS AND THEIR CYCLOADDUCTS WITH AMINOTHIOLS: CHEMOINFORMATIC ANALYSIS
}

Skarga $W^{1,2}$, Zadorozhny $A D^{1}$, Shilov $B^{1}{ }^{1}$, Nevezhin $E^{1}$, Negrebetsky $W^{1}$, Maslov $M^{2}{ }^{2}$, Lagunin $A A^{1,3}$, Malakhov MV

${ }^{1}$ Pirogov Russian National Research Medical University, Moscow, Russia

${ }^{2}$ MIREA — Russian Technological University, Moscow, Russia

${ }^{3}$ Institute of Biomedical Chemistry (IBMC), Moscow, Russia

Psoralens are medicinal photosensitizing furocoumarins which are used in photochemotherapy and photoimmunotherapy of dermatoses. Psoralen photooxidation products may be involved in therapeutic effects, but the possible mechanisms of their action remain unclear. The study was aimed to assess the prospective pharmacological effects and mechanisms of activity for six previously identified ortho-hydroxyformyl-containing psoralen photooxidation products and their cycloadducts with aminothiols, as well as for structurally similar compounds (furocoumaric acid and tucaresol). Chemoinformatic analysis of the prospective pharmacological effects and mechanisms of action of these compounds was performed using the PASS and PharmaExpert software. The predicted pharmacological effects partially confirmed by previous studies highlight the possible involvement of psoralen photooxidation products in the effects of PUVA therapy or photopheresis during the course of dermatoses and proliferative disorders treatment. A broad spectrum of pharmacological effects found for furocoumaric acid and cycloadducts of coumarinic and benzofuranic photoproducts of psoralen with cysteine and homocysteine appoints new directions of research relating to therapeutic use of psoralens.

Keywords: psoralens, coumarins, benzofurans, aldehydes, furocoumaric acid, aminothiols, (Q)SAR, PASS, PharmaExpert

Funding: the study was supported by RFBR, project number 19-33-90277.

Author contribution: Skarga W - literature analysis, data analysis and interpretation, manuscript writing and editing; Zadorozhny AD, Shilov BV — data acquisition and analysis; Nevezhin EV — literature analysis, data interpretation; Negrebetsky W — data interpretation, manuscript writing; Maslov MA — study design; Lagunin AA — study design, literature analysis, manuscript writing; Malakhov MV — study design, literature analysis, data interpretation, manuscript writing and editing.

$\triangle$ Correspondence should be addressed: Vladislav V. Skarga Ostrovityanova, 1, Moscow, 117437; skargavlad@gmail.com

Received: 27.08.2020 Accepted: 22.09.2020 Published online: 09.10.2020

DOI: $10.24075 /$ brsmu.2020.059

\section{ПОТЕНЦИАЛЬНЫЕ ФАРМАКОЛОГИЧЕСКИЕ ЭФФЕКТЫ ПРОДУКТОВ ФОТООКИСЛЕНИЯ ПСОРАЛЕНА И ИХ ЦИКЛОАДДУКТОВ С АМИНОТИОЛАМИ: ХЕМОИНФОРМАЦИОННЫЙ АНАЛИЗ}

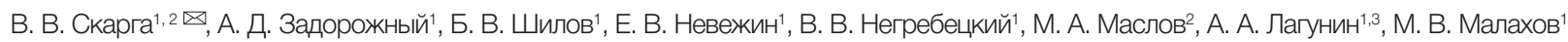 \\ ${ }^{1}$ Российский национальный исследовательский медицинский университет имени Н. И. Пирогова, Москва, Россия \\ ${ }^{2}$ МИРЭА — Российский технологический университет, Москва, Россия \\ ${ }^{3}$ Научно-исследовательский институт биомедицинской химии имени В. Н. Ореховича, Москва, Россия
}

Псоралены, медицинские фотосенсибилизаторы фурокумаринового ряда, используют для фотохимиотерапии и фотоиммунотерапии дерматозов. Продукты фотоокисления псораленов могут принимать участие в реализации терапевтических эффектов, однако возможные механизмы их действия остаются неизвестны. Основной целью работы было оценить потенциальные фармакологические эффекты и возможные механизмы действия шести ранее идентифицированных продуктов фотоокисления псоралена, характеризующихся наличием орто-гидроксиформильной группировки, их циклоаддуктов с аминотиолами, а также структурно родственных соединений (фурокумариновой кислоты и тукарезола). Хемоинформационный анализ потенциальных фармакологических эффектов и возможных механизмов действия указанных соединений был проведен с использованием программ PASS и PharmaExpert. Предсказанные фармакологические эффекты, частично подтверждаемые результатами ранее проведенных исследований, свидетельствуют о возможном участии продуктов фотоокисления псораленов в реализации эффектов PUVA-терапии или фотофереза при лечении ряда дерматозов и пролиферативных патологий. Широкий спектр фармакологических эффектов, обнаруженный для фурокумариновой кислоты и циклоаддуктов кумариновых и бензофурановых фотопродуктов псоралена с цистеином и гомоцистеином, определяет новые направления исследований в области терапевтического применения псораленов.

Ключевые слова: псоралены, кумарины, бензофураны, альдегиды, фурокумариновая кислота, аминотиолы, (Q)SAR, PASS, PharmaExреrt Финансирование: исследование выполнено при финансовой поддержке РФФИ в рамках научного проекта № 19-33-90277.

Вклад авторов: В. В. Скарга - анализ литературы, анализ и интерпретация данных, подготовка и окончательная редакция текста рукописи; А. Д. Задорожный, Б. В. Шилов - сбор и анализ данных; Е. В. Невежин - анализ литературы, интерпретация данных; В. В. Негребецкий интерпретация данных, подготовка текста рукописи; М. А. Маслов - дизайн исследования; А. А. Лагунин - дизайн исследования, анализ литературы, подготовка текста рукописи; М. В. Малахов - дизайн исследования, анализ литературы, интерпретация данных, подготовка и окончательная редакция текста рукописи.

$\triangle$ Для корреспонденции: Владислав Викторович Скарга ул. Островитянова, д. 1, г. Москва, 117437; skargavlad@gmail.com

Статья получена: 27.08.2020 Статья принята к печати: 22.09.2020 Опубликована онлайн: 09.10.2020

DOI: $10.24075 /$ vrgmu.2020.059

Psoralens are plant-derived or synthetic linear furanocoumarins which are able to sensitize biological objects to near-ultraviolet radiation (UVA, 320-400 nm) [1]. PUVA (Psoralen and UV-A) therapy and extracorporeal photopheresis, both based on photosensitizing effects of psoralens, are widely used in medicine for treatment of such disorders as psoriasis, vitiligo, atopic dermatitis, eczema, cutaneous T-cell lymphoma, scleroderma (systemic sclerosis), graft-versus-host reaction and a number of other diseases [2-9]. PUVA therapy and photopheresis are now understood to be based on antiproliferative and apoptotic 
effects towards keratinocytes and immunocompetent cells, as well as on induction of immunosuppression, i.e. the described treatment methods should be considered as photochemotherapy and photoimmunotherapy [2-9]. It is important to emphasize that for the reasons of versatility, costefficiency and safety, the clinical significance of PUVA therapy and photopheresis does not depreciate in the modern era of biologics development and use [6, 7, 9].

During PUVA therapy or photopheresis, the patient's skin or leukapack derived therefrom, respectively, are exposed to PUVA treatment. Previously, we have proposed the treatment modality for psoriasis, atopic dermatitis and eczema based on oral administration to patients of psoralen preliminary photooxidized in vitro (POP) and able to induce the immunotherapeutic effect in vivo $[10,11]$. The described effect was studied in the murine model of contact hypersensitivity to dinitrofluorobenzene (DNFB) being an experimental analogue of atopic dermatitis in humans $[11,12]$. It was shown that POP modulated the production of secretory cytokines by the lymph node cells of DNBF-sensitized mice. POP reduced production of IL2, IL4 and IFN- $\gamma$, increased secretion of IL17, but did not affect the production of IL6 and IL10 [11]. Furthermore, it was found that administration of POP to DNBF-sensitized mice resulted in reduced number of cells in the regional lymph nodes, decreased proliferative activity of cells, and apoptosis induction [11]. The results obtained were consistent with the modern concepts on the molecular basis of PUVA therapy and photopheresis [2-9], and made it possible to consider POP as a prospective agent for treatment of pathologies caused by T-cell immunity hyperresponsiveness.

It is known that POP is a complex mixture of photoproducts produced during the photolysis of aerated psoralen solution in vitro $[13,14]$. However, only some of those were isolated from mixture and chemically identified due to extremely low yield in photoreactions and instability during separation and/ or analytical procedures [13-16]. The in vitro analysis of photooxidized psoralens revealed their apoptotic activity $[16,17]$, as well as the ability to affect cell proliferation and differentiation $[15,17]$. It is noteworthy that apoptotic effect was observed only in the transformed T-cell lines (Jurkat cell line), whereas in normal lymphocytes derived from healthy donors no apoptotic effects were detected [16]. That observation makes it possible to suggest that the apoptotic activity of psoralen photoproducts is specific, and that photoproducts play a vital part in PUVA therapy and photopheresis effects.

Currently, chemoinformatics is widely used to predict the biological activity of organic compounds. The software products created for this purpose enable the precise prediction of biological activity profiles based on the structural formulae of low molecular weight compounds under study [18-22].

The present study was aimed to assess the prospective pharmacological effects and mechanisms of action for previously identified psoralen photooxidation products and their cycloadducts with aminothiols, to reveal correlations between the results of chemoinformatic analysis and previously reported immunotropic (therapeutic) effects of such products, as well as to appoint new directions of research in this field.

\section{METHODS}

The prospective pharmacological effects were predicted using the PASS (Prediction of Activity Spectra for Substances) software ver. 2019 (IBMC; Russia) [18, 19] making it possible to assess the biological activity profile of an organic compound based on its structural formula. Assessment is based on the structure-activity relationship analysis of the training set including more than one million of compounds tested for biological activity. In the PASS software, the biological activity is presented qualitatively (active/inactive). The chemical structure is represented by the MNA (Multilevel Neighborhoods of Atoms) descriptors [20]. The algorithm of the structure-activity relationship modeling based on the training set compounds, and the new compounds activity prediction uses the modified Bayesian algorithm $[18,19]$. The used version of PASS software (PASS 2019) predicts over 5000 different types of biological activity, including therapeutic effects, 3818 mechanisms of action, and side effects with average accuracy of about 95\% (leave-one-out cross-validation procedure).

The information on structural formula of the compound presented in the Molfile format is used as the PASS input data. The list of predicted activities with probabilities "to be active" $P_{a}$ and "to be inactive" $P$, varying from 0 to 1 is generated as the output. The probabilities $P_{a}$ and $P_{i}$ are also estimates of the type I and type II error probabilities, respectively, and may be considered as a measure of the predicted compound assignment to the subset of "active" or "inactive" substances. For specific type of activity, the greater $P_{a}$ value and the smaller $P$, value are predicted, the higher is the chance to confirm the predicted activity by experiment.

In the present study, prediction and analysis of prospective pharmacological effects and corresponding mechanisms of action were performed using the PharmaExpert ver. 2019 software (IBMC; Russia) [21] with 50\% cut-off probability of predicted activity signs (the activity was considered probable when the $P_{a}$ value was above 0.5 and exceeded the $P_{i}$ value). The PharmaExpert software is intended for analysis of PASS prediction results, which are based on the "target-pathwayeffect" relationships stored in the PharmaExpert database (current version, issued in 2019, contains information for more than 15,000 such relationships).

The molecular structures of compounds under study were used in the search for identical and similar compounds in PubChem, the largest free database containing data (both experimental and patent) on molecular structure and biological activity for more than 100 million chemical compounds [22]. The search for identical and similar compounds is based on their structure description as PubChem fingerprints (881-bit vectors describing the structural features of the compounds). It is known that compounds with similar structure may exhibit similar activity, and identification of similar compounds with known biological activity may help in planning experimental studies. In the present study, the PubChem built-in tool using the Tanimoto coefficient calculated from PubChem fingerprints as a measure of structural similarity was used for similaritybased search [23]:

$$
T(X, Y)=(N(X \cap Y)) /(N(X \cup Y)),
$$

where $N(X \cap Y)$ was the number of common descriptors for compounds $X$ and $Y$, and $N(X \cup Y)$ was the total number of unique descriptors for compounds $X$ and $Y$. The Tanimoto coefficient values exceeding 0.9 and 0.8 were used as a threshold for similarity evaluation.

\section{RESULTS}

\section{Rationale for selection of research objects}

It is known that the formation of photoproducts possessing immunotropic (therapeutic) effect strictly depends on the 
Table 1. Coumarinic POP products

\begin{tabular}{|c|c|c|c|}
\hline $\mathrm{OHC}$ & $\begin{array}{c}\mathrm{R}_{1}=\mathrm{H} \\
\mathrm{R}_{2}=\mathrm{H} \\
\quad 1\end{array}$ & $\begin{array}{c}\mathrm{R}_{1}=\mathrm{H} \\
\mathrm{R}_{2}=\mathrm{OMe} \\
2\end{array}$ & $\begin{array}{c}\mathrm{R}_{1}=\mathrm{OMe} \\
\mathrm{R}_{2}=\mathrm{H} \\
3\end{array}$ \\
\hline Pharmacological effects & \multicolumn{3}{|c|}{$P_{a} / P_{i}$} \\
\hline Immunosuppressive & - & - & $0.541 / 0.036$ \\
\hline Apoptotic & $0.899 / 0.004$ & $0.915 / 0.004$ & $0.764 / 0.010$ \\
\hline Antitumor & $0.741 / 0.019$ & $0.763 / 0.017$ & $0.751 / 0.018$ \\
\hline Cytostatic & $0.538 / 0.020$ & $0.586 / 0.015$ & $0.516 / 0.023$ \\
\hline Antimutagenic & $0.807 / 0.004$ & $0.760 / 0.005$ & $0.774 / 0.004$ \\
\hline Radioprotective & $0.701 / 0.010$ & - & $0.766 / 0.006$ \\
\hline Analeptic & $0.791 / 0.005$ & $0.769 / 0.007$ & $0.687 / 0.011$ \\
\hline Antifungal & $0.620 / 0.016$ & $0.631 / 0.015$ & $0.584 / 0.020$ \\
\hline Antiprotozoal (Trypanosoma) & $0.537 / 0.014$ & - & - \\
\hline Antiparasitic & $0.513 / 0.014$ & $0.519 / 0.014$ & - \\
\hline Anthelmintic (nematodes) & $0.512 / 0.015$ & - & - \\
\hline Antimycobacterial & $0.506 / 0.018$ & - & - \\
\hline
\end{tabular}

presence of oxygen during irradiation of psoralen solution [10]. That makes it possible to limit the search by previously characterized psoralen photooxidation products (POP products). Photolysis products of furocoumarins and the pathways leading to their formation are exhaustively reviewed [13]. This review demonstrated that all processes involving oxidative modification of psoralen and other furocoumarins could be divided into three sets. The first set consists of oxidative furan or pyrone ring opening photoproducts classified as coumarins and benzofurans, respectively. The second set includes photoproducts formed by addition of a solvent molecule to the furan ring of photooxidation intermediate. The third set consists of photoproducts formed during double modification of psoralen molecule, with at least one being oxidative.

After the analysis of literature data on biological activity had been done, we decided to focus on POP products referring to the first set. Coumarins and benzofurans formed during photooxidation of furocoumarins are known to contain orthohydroxyformyl (OHF) arrangement as the fingerprint and possess the biological activity described above $[13,15,16]$. It was suggested [13] that biological activity of POP products from the first set was due to presence of OHF, similarly to well known immunomodulator tucaresol [24]. That was partially confirmed by the paper reporting the apoptogenic effect of several OHFcontaining compounds [16]. Previously, we have shown that OHF-containing photooxidation products of protoporphyrin IX possessed immunotropic activity inducing suppression of contact hypersensitivity reaction in mice [25].

Thus, we determined the set of compounds for chemoinformatic analysis using the PASS and PharmaExpert software. This set includes the OHF-containing coumarinic POP products (compounds 1-3) previously identified for psoralen, 8methoxypsoralen (8-MOP) and 5-methoxypsoralen (5-MOP), the main furocoumarinic photosensitizers used in medicine [2-9]. The set also includes the known OHF-containing benzofuranic POP products of the three psoralens listed above (compounds 4-6). The OHF-containing tucaresol (compound 7) was added to the set as a reference compound with the known immunotropic effect based on T-cells stimulation by means of Schiff base formation with T-cell receptors [24]. Furthermore, the prospective pharmacological effects of the furocoumaric acid (compound 8), the psoralen photoproduct suspected of being an intermediate on the pathway to compound 4 during the psoralen photooxidation, were analyzed [26]. A distinct group includes cycloadducts of the OHF-containing POP products with cysteine and homocysteine (compounds 9-12 and 13-16 for coumarinic and benzofuranic POP products, respectively). In the present study, the choice of cysteine and homocysteine is not random. It is known that the OHF-containing coumarins (in particular, 8-formylumbelliferone) are used for fluorometric analysis of above-mentioned amino acids in biological objects [27], and their adducts with amines possess biological activity [28].

\section{Predicted pharmacological effects of POP products, furocoumaric acid and tucaresol}

Tables 1 and 2 summarize the major results of chemoinformatic analysis for the target POP products (compounds 1-6). The only compound with predicted immunotropic (immunosuppressive) activity is coumarinic POP product of 5-MOP. Instead, the high probability of apoptosis inducing activity is predicted for all compounds, with $P / P$, values for the described type of activity being higher in coumarinic POP products compared to benzofuranic POP products. Furthermore, the antitumor and cytostatic effects are predicted for compounds 1-6.

In addition to the types of antiproliferative activity listed above, the high probability of respiratory (compounds 1-5) and to a lesser extent cardiovascular (compounds 1, 2) analeptic activities, as well as antimutagenic (compounds 1-6) and radioprotective (compounds 1, 3, 4 and 6) activities are predicted. Several other protective types of activity are expected for benzofuranic POP products, especially for compound 4 (vasoprotective, neuroprotective and cardioprotective activities).

The results of analysis demonstrate the broad spectrum of expected antibiotic activity: antifungal activity is predicted for compounds $1-6$, and compound 1 is characterized by five types of antibiotic activity at once. When comparing, it can be noted that the antibiotic activity of coumarinic POP products is higher compared to benzofuranic POP products, both in qualitative and quantitative terms. 
Table 2. Benzofuranic POP products

\begin{tabular}{|c|c|c|c|}
\hline $\mathrm{R}_{2}$ & $\begin{array}{c}\mathrm{R}_{1}=\mathrm{H} \\
\mathrm{R}_{2}=\mathrm{H} \\
4\end{array}$ & $\begin{array}{c}\mathrm{R}_{1}=\mathrm{H} \\
\mathrm{R}_{2}=\mathrm{OMe} \\
5\end{array}$ & $\begin{array}{c}\mathrm{R}_{1}=\mathrm{OMe} \\
\mathrm{R}_{2}=\mathrm{H} \\
6\end{array}$ \\
\hline Pharmacological effects & \multicolumn{3}{|c|}{$P_{a} / P_{i}$} \\
\hline Apoptotic & $0.884 / 0.005$ & $0.906 / 0.004$ & $0.702 / 0.015$ \\
\hline Antitumor & $0.565 / 0.053$ & $0.635 / 0.038$ & $0.613 / 0.042$ \\
\hline Cytostatic & - & $0.532 / 0.021$ & - \\
\hline Antimutagenic & $0.780 / 0.004$ & $0.724 / 0.005$ & $0.741 / 0.005$ \\
\hline Radioprotective & $0.662 / 0.012$ & - & $0.746 / 0.008$ \\
\hline Analeptic & $0.580 / 0.021$ & $0.532 / 0.027$ & - \\
\hline Antifungal & $0.531 / 0.026$ & $0.548 / 0.024$ & - \\
\hline Antimycobacterial & $0.510 / 0.180$ & - & - \\
\hline Vasoprotective & $0.732 / 0.009$ & $0.550 / 0.028$ & $0.523 / 0.034$ \\
\hline Neuroprotective & $0.640 / 0.058$ & - & $0.586 / 0.080$ \\
\hline Cardioprotective & $0.539 / 0.008$ & - & - \\
\hline
\end{tabular}

Analysis of predicted mechanisms of action for the types of activity described above leads to the conclusion that antiproliferative activities of the studied compounds may be mediated by their action as apoptosis agonists, and as inhibitors of a number of enzymes (phosphatases, kinases, monophenol oxygenase) and transcription factors (for example, NF-kB transcription factor). Radioprotective properties may be associated with the ability to inhibit the permeability and promote the integrity of membranes, as well as to act as a free radical scavenger. Antibiotic activity presumably results from the effect of compounds on transmembrane processes and functioning of kinases and membrane proteins (for example, inhibiting the ampH penicillin-binding protein).

Table 3 presents the results on prediction of major pharmacological effects for tucaresol. According to the analysis,

Table 3. Tucaresol with a high probability tucaresol possesses anti-inflammatory activity in intestine, as well as neurotropic protective effects (antineurotoxic and neuroprotective activities).

The profiles of the pharmacological effects predicted for furocoumaric acid were found to be surprisingly broad (Table 4). It is assumed that acting mainly as a free radical scavenger and maintaining the integrity of membranes furocoumaric acid provides a wide range of protective effects (including antimutagenic, neuroprotective, vasoprotective, radioprotective, anticarcinogenic, etc.), affects metabolic pathways (regulates lipid metabolism, reduces cholesterolemia), provides anti-inflammatory and antioxidant protection, and also possesses prospective dermatologic (in particular, antipsoriatic) therapeutic activity due to anti-inflammatory effect and regulation of enzymatic activity.

\begin{tabular}{|l|l|}
\hline \multicolumn{1}{|c|}{ Pharmacological effects } & \\
\hline & \\
\hline Anti-inflammatory (intestine) & \\
\hline Treatment of sickle cell disease & \\
\hline Antineurotoxic & \\
\hline Neuroprotective & \\
\hline Antiprotozoal (leishmania) & \\
\hline Treatment of precancerous lesions & \\
\hline Cytoprotective & \\
\hline Radioprotective & \\
\hline
\end{tabular}




\begin{tabular}{|l|l|}
\hline \multicolumn{1}{|c|}{ Pharmacological effects } & \\
\hline Antimutagenic & $0.896 / 0.002$ \\
\hline Neuroprotective & $0.754 / 0.018$ \\
\hline Vasoprotective & $0.720 / 0.006$ \\
\hline Regulation of lipid metabolism & $0.676 / 0.012$ \\
\hline Antihypercholesterolemic & $0.669 / 0.011$ \\
\hline Radioprotective & $0.643 / 0.011$ \\
\hline Anticarcinogenic & $0.631 / 0.013$ \\
\hline Antipyretic & $0.566 / 0.009$ \\
\hline Dermatologic & $0.530 / 0.028$ \\
\hline Anti-inflammatory & $0.523 / 0.033$ \\
\hline Antioxidant & $0.520 / 0.006$ \\
\hline
\end{tabular}

\section{Predicted pharmacological effects of OHF-containing POP products adducts with aminothiols}

Tables 5 and 6 present pharmacological effects predicted for cycloadducts of the OHF-containing POP products with aminothiols. Reaction of coumarinic compound 1 with cysteine and homocysteine results in formation of corresponding cycloadducts (see Table 5, compounds 9 and 11). Oxidation of compounds 9 and 11 leads to formation of compounds 10 and 12 , respectively (see Table 5). Similarly, the appropriate cycloadducts may be obtained for benzofuranic compound 4 (see Table 6, compounds 13-16).

According to the analysis, compounds 9-15 may function as radioprotectors, with such property being associated with the ability to scavenge free radicals is more likely for nonoxidized cycloadducts (compounds 9, 11, 13, 15). In

Table 5. Coumarinic POP products cycloadducts with aminothiols addition, it is assumed that compounds 9, 11, 13 and 15 (but not their oxidized forms 10,12, 14 and 16) possess antitumor activity against a number of malignant neoplasms, such as prostate cancer, liver cancer, and melanoma. For compounds 9-16 hepatoprotective activity is predicted, which may be used for treatment of liver diseases. As with radioprotective properties, this pharmacological effect is attributed to the functioning of compounds 9-16 as reducing agents and free radical scavengers. According to prediction, coumarinic cycloadducts 9-12 possess spasmolytic activity which is realized in urinary tract, with such type of activity not being predicted for benzofuranic cycloadducts 13-16. All oxidized forms of cycloadducts (compounds 10, 12, 14 and 16) are presumably applicable for treatment of neurodegenerative diseases, and compounds 10 and 12 are also potentially active when used in dermatology.

\begin{tabular}{|l|l|l|l|l|}
\hline \multicolumn{1}{|c|}{ Pharmacological effects } & $0.857 / 0.003$ & $0.569 / 0.015$ & $0.800 / 0.005$ & $0.513 / 0.021$ \\
\hline Radioprotective & $0.734 / 0.004$ & - & $0.640 / 0.005$ \\
\hline Treatment of prostate cancer & $0.661 / 0.004$ & - & $0.540 / 0.006$ \\
\hline Antitumor (melanoma) & $0.563 / 0.003$ & - & $0.503 / 0.003$ & - \\
\hline Antitumor (liver cancer) & $0.700 / 0.004$ & $0.683 / 0.004$ & $0.555 / 0.008$ & $0.614 / 0.005$ \\
\hline Treatment of liver diseases & $0.525 / 0.021$ & $0.577 / 0.013$ & $0.512 / 0.023$ & $0.563 / 0.015$ \\
\hline Antispasmodic (urinary tract) & - & $0.528 / 0.027$ & - & $0.603 / 0.016$ \\
\hline Treatment of neurodegenerative diseases & - & $0.522 / 0.029$ & - & $0.585 / 0.019$ \\
\hline Dermatologic & 9 & -10 \\
\hline
\end{tabular}




\begin{tabular}{|c|c|c|c|c|}
\hline & \multicolumn{4}{|c|}{$\mathrm{R}$} \\
\hline${ }_{\mathrm{OH}}^{\mathrm{R}}$ & $\sum_{13}^{\mathrm{SO}}$ & $\sum_{14}^{\mathrm{S}}$ & (15 & ${ }^{\mathrm{HO}}$ \\
\hline Pharmacological effects & \multicolumn{4}{|c|}{$P_{a} / P_{i}$} \\
\hline Radioprotective & $0.843 / 0.004$ & $0.531 / 0.019$ & $0.783 / 0.005$ & - \\
\hline Treatment of prostate cancer & $0.710 / 0.004$ & - & $0.621 / 0.006$ & - \\
\hline Antitumor (melanoma) & $0.670 / 0.004$ & - & $0.549 / 0.005$ & - \\
\hline Antitumor (liver cancer) & $0.579 / 0.003$ & - & $0.510 / 0.003$ & - \\
\hline Treatment of liver diseases & $0.689 / 0.004$ & $0.672 / 0.004$ & $0.542 / 0.008$ & $0.601 / 0.005$ \\
\hline Treatment of neurodegenerative diseases & - & $0.658 / 0.011$ & - & $0.707 / 0.008$ \\
\hline
\end{tabular}

\section{DISCUSSION}

The described results of the present study are consistent with literature data. Previously, it has been found that compounds 1 and 2 were apoptosis inducers [16], and the psoralen derivatives were able to inhibit the activity of NF-kB transcription factor [29]. Furthermore, the predicted antitumor and cytostatic activity of compounds 1-6 may explain some previously detected effects of POP and individual photoproducts. Thus, antitumor activity of POP was revealed in the in vivo experiments with murine EL-4 lymphoma as a model of human cutaneous T-cell lymphoma [10], and the benzofuranic POP product (compound 4) possessed teratogenic effect in the experiments on the Xenopus lavrae embryos [15].

In addition, it has been previously shown that tucaresol used by us as the reference compound with known immunotropic activity, possessed antiprotozoal activity in the experimental model of visceral leishmaniasis [30], and was also applicable for treatment of patients with sickle cell anemia [31]. It is noteworthy that the possible use of psoralen photooxidation products for treatment of $\beta$-thalassemia and sickle cell anemia has also been reported [17].

Of particular interest is the unexpected discovery of the prospective dermatologic (in particular, antipsoriatic) therapeutic activity of furocoumaric acid resulting from anti-inflammatory effect and regulation of enzymatic activity. The latter two types of biological activity are typical for cinnamic acid derivatives [32], and presumably implemented by furocoumaric acid by means of free radical scavenging, inhibiting lipoxygenase and transcription factors, and maintaining the integrity of membranes.

Oxidized forms of coumarinic cycloadducts with aminothiols potentially possess dermatologic therapeutic activity, but the predicted activity of the OHF-containing psoralen photooxidation products on homocysteine is of greater interest. It is known that elevated level and/or accumulation of homocysteine may result in a variety of pathologic conditions (Alzheimer's disease, senile dementia, vascular disorders, nephropathy, etc.) [33]. Hence, the predicted therapeutic activity of oxidized cycloadducts resulting from reaction of the OHF-containing psoralen photooxidation products with homocysteine may determine the prospects of their practical usage for therapy of the abovementioned pathologies.

\section{CONCLUSION}

In the present study, chemoinformatic assessment of prospective pharmacological effects and mechanisms of action for previously identified psoralen photooxidation products and their cycloadducts with aminothiols was performed using the PASS and PharmaExpert software. Several predicted pharmacological effects are confirmed with the results of earlier studies, which indicate high prediction efficiency of the analysis. In terms of actual usage of psoralens for treatment of various dermatoses and proliferative disorders, the data obtained are indicative of the possible involvement of psoralen photooxidation products in the realization of the therapeutic effects of PUVA therapy and photopheresis, and therefore are especially valuable. Of special interest is the surprisingly broad spectrum of pharmacological effects found for furocoumaric acid and cycloadducts of coumarinic and benzofuranic photoproducts of psoralen with aminothiols, which appoints new directions of research related to therapeutic use of psoralens.

\section{References}

1. Bruni R, Barreca D, Protti M, Brighenti V, Righetti L, Anceschi L, et al. Botanical Sources, Chemistry, Analysis, and Biological Activity of Furanocoumarins of Pharmaceutical Interest. Molecules. 2019; 24 (11): 2163. DOI: 10.3390/molecules24112163.

2. Trautinger $F$, Just $U$, Knobler R. Photopheresis (extracorporeal photochemotherapy). Photochem Photobiol Sci. 2013; 12 (1): 22-8. DOI: 10.1039/c2pp25144b.

3. Racz E, Prens EP. Phototherapy and photochemotherapy for psoriasis. Dermatol Clin. 2015; 33 (1): 79-89. DOI: 10.1016/j. det.2014.09.007.

4. Bae JM, Jung HM, Hong BY, Lee JH, Choi WJ, Lee JH, et al. Phototherapy for Vitiligo: A Systematic Review and Metaanalysis. JAMA Dermatol. 2017; 153 (7): 666-674. DOI: 10.1001/ jamadermatol.2017.0002.

5. Chaowattanapanit S, Choonhakarn C, Foocharoen C, Julanon N Phototherapy in systemic sclerosis: Review. Photodermatol 
Photoimmunol Photomed. 2017; 33 (6): 296-305. DOI: 10.1111/ phpp.12331.

6. Guitart J. Psoralen Plus UV-A Therapy in the 21st Century: Use It or Lose It. JAMA Dermatol. 2019; 155 (5): 529-31. DOI: 10.1001/ jamadermatol.2018.5844.

7. Richard EG. The Science and (Lost) Art of Psoralen Plus UVA Phototherapy. Dermatol Clin. 2020; 38 (1): 11-23. DOI: 10.1016/j. det.2019.08.002.

8. Vieyra-Garcia PA, Wolf P. Extracorporeal Photopheresis: A Case of Immunotherapy Ahead of Its Time. Transfus Med Hemother. 2020; 47 (3): 226-35. DOI: 10.1159/000508479.

9. Torres AE, Lyons AB, Hamzavi IH, Lim HW. Role of phototherapy in the era of biologics. J Am Acad Dermatol. 2020; S0190-9622 (20): 30711-8. DOI: 10.1016/j.jaad.2020.04.09.

10. Potapenko AYa, Kyagova AA, Bezdetnaya LN, Lysenko EP, Chernyakhovskaya IYu, Bekhalo VA, et al. Products of psoralen photooxidation possess immunomodulative and antileukemic effects. Photochem Photobiol. 1994; 60 (2): 171-4. DOI: 10.1111/j.1751-1097.1994.tb05086.x.

11. Pyatnitskiy IA, Pavlova SI, Albegova DZ, Kozlov IG, Potapenko AY, Kyagova AA. Suppressive effects of psoralene photooxidation products on contact sensitivity reaction in mice: lymphocyte proliferation inhibition and apoptosis induction. Russian journal of skin and venereal diseases. 2013; 6: 59-63. Russian.

12. Honda T, Egawa G, Grabbe S, Kabashima K. Update of immune events in the murine contact hypersensitivity model: toward the understanding of allergic contact dermatitis. J Invest Dermatol. 2013; 133 (2): 303-15. DOI: 10.1038/iid.2012.284.

13. Caffieri S. Furocoumarin photolysis: chemical and biological aspects. Photochem Photobiol Sci. 2002; 1 (3): 149-57. DOl: 10.1039/b107329j.

14. Potapenko AYa, Malakhov MV, Kyagova AA. Photobiophysics of furocoumarins. Biophysics. 2004; 49 (2): 307-24.

15. Marley KA, Larson RA, Davenport R. Alternative mechanisms of psoralen phototoxicity. ACS Symposium Series. 1995; 616 (15): 179-88. DOI: 10.1021/bk-1995-0616.ch015.

16. Caffieri S, Di Lisa F, Bolesani F, Facco M, Semenzato G, Dall'Acqua F, et al. The mitochondrial effects of novel apoptogenic molecules generated by psoralen photolysis as a crucial mechanism in PUVA therapy. Blood. 2007; 109 (11): 4988-94. DOI: 10.1182/ blood-2006-08-037192.

17. Viola G, Salvador A, Vedaldi D, Dall'Acqua F, Bianchi N, Zuccato C, et al. Differentiation and apoptosis in UVA-irradiated cells treated with furocoumarin derivatives. Ann NY Acad Sci. 2009; 1171: 334-44. DOI: 10.1111/j.1749-6632.2009.04894.x.

18. Filimonov DA, Lagunin AA, Gloriozova TA, Rudik AV, Druzhilovskij DS, Pogodin PV i dr. Predskazanie spektrov biologicheskoj aktivnosti organicheskih soedinenij ispol'zuja vebresurs PASS Online. Himija geterociklicheskih soedinenij. 2014; 50 (3): 483-99. DOI: 10.1007/s10593-014-1496-1.

19. Filimonov DA, Druzhilovskii DS, Lagunin AA, Gloriozova TA, Rudik AV, Dmitriev AV, Pogodin PV, Poroikov W. Computer prediction of the spectra of biological activity of chemical compounds: possibilities and limitations. Biomedical Chemistry: Research and Methods.
2018; 1 (1): e00004. DOI: 10.18097/BMCRM00004.

20. Filimonov D, Poroikov V, Borodina Yu, Gloriozova T. Chemical Similarity Assessment through Multilevel Neighborhoods of Atoms: Definition and Comparison with the Other Descriptors. J Chem Inf Comput Sci. 1999; 39 (4): 666-70. DOI: 10.1021/ci980335o.

21. Lagunin AA, Goel RK, Gawande DY, Pahwa P, Gloriozova TA, Dmitriev AV, et al. Chemo- and bioinformatics resources for in silico drug discovery from medicinal plants beyond their traditional use: a critical review. Nat Prod Rep. 2014; 31 (11): 1585-611. DOI: 10.1039/c4np00068d.

22. Kim S, Chen J, Cheng T, Gindulyte A, He J, He S, et al. PubChem 2019 update: improved access to chemical data. Nucleic Acids Res. 2019; 47 (D1): D1102-9. DOI: 10.1093/nar/gky1033.

23. Willett $P$. Similarity-based virtual screening using $2 \mathrm{D}$ fingerprints. Drug Discov Today. 2006; 11 (23-24): 1046-53.

24. Chen H, Hall S, Zheng B, Rhodes J. Potentiation of the Immune System by Schiff Base-Forming Drugs. BioDrugs. 1997; 7 (3): 217-31. DOI: 10.2165/00063030-199707030-00005.

25. Kyagova AA, Mansurova GV, Kozir LA, Ponomarev GV, Pavlov VY, Konstantinov IO, et al. Systemic suppression of the contact hypersensitivity by the products of protoporphyrin IX photooxidation. Photochem Photobiol. 2005; 81 (6): 1380-5. DOI: 10.1562/2005-04-26-RA-500.

26. Nevezhin EV, Vlasova NV, Pyatnitskiy IA, Lysenko EP, Malakhov MV. On the mechanism of erythrocyte hemolysis induced by photooxidized psoralen. Biochemistry (Moscow). 2015; 80 (6): 763-8. DOI: 10.1134/S0006297915060115

27. Yin C, Huo F, Zhang J, Martínez-Máñez R, Yang Y, Lv H, et al. Thiol-addition reactions and their applications in thiol recognition. Chem Soc Rev. 2013; 42 (14): 6032-59. DOI: 10.1039/c3cs60055f.

28. Patil SA, Prabhakara CT, Halasangi BM, Toragalmath SS, Badami PS. DNA cleavage, antibacterial, antifungal and anthelmintic studies of $\mathrm{Co}(\mathrm{II}), \mathrm{Ni}(\mathrm{II})$ and $\mathrm{Cu}(\mathrm{II})$ complexes of coumarin Schiff bases: synthesis and spectral approach. Spectrochim Acta A Mol Biomol Spectrosc. 2015; 137: 641-51. DOI: 10.1016/j.saa.2014.08.028.

29. Marzaro F, Lampronti I, Borgatti M, Manzini P, Gambari R, Chilin A. Psoralen derivatives as inhibitors of NF kB DNA interaction - the critical role of the furan ring. Mol Divers. 2015; 19 (3): 551-61. DOI: 10.1007/s11030-015-9586-2.

30. Smith AC, Yardley V, Rhodes J, Croft SL. Activity of the novel immunomodulatory compound tucaresol against experimental visceral leishmaniasis. Antimicrob Agents Chemother. 2000; 44 (6): 1494-8. DOI: 10.1128/aac.44.6.1494-1498.2000.

31. Arya R, Rolan PE, Wootton R, Posner J, Bellingham AJ. Tucaresol increases oxygen affinity and reduces haemolysis in subjects with sickle cell anaemia. Br J Haematol. 1996; 93 (4): 817-21. DOI: 10.1046/j.1365-2141.1996.d01-1744.x.

32. Sova M. Antioxidant and antimicrobial activities of cinnamic acid derivatives. Mini Rev Med Chem. 2012; 12 (8): 749-67. DOI: 10.2174/138955712801264792.

33. Zaric BL, Obradovic $M$, Bajic $V$, Haidara MA, Jovanovic $M$, Isenovic ER. Homocysteine and Hyperhomocysteinaemia. Curr Med Chem. 2019; 26 (16): 2948-61. DOI: 10.2174/092986732 5666180313105949

\section{Литература}

1. Bruni R, Barreca D, Protti M, Brighenti V, Righetti L, Anceschi L, et al. Botanical Sources, Chemistry, Analysis, and Biological Activity of Furanocoumarins of Pharmaceutical Interest. Molecules. 2019; 24 (11): 2163. DOI: 10.3390/molecules24112163.

2. Trautinger F, Just $U$, Knobler R. Photopheresis (extracorporeal photochemotherapy). Photochem Photobiol Sci. 2013; 12 (1): 22-8. DOI: 10.1039/c2pp25144b.

3. Racz E, Prens EP. Phototherapy and photochemotherapy for psoriasis. Dermatol Clin. 2015; 33 (1): 79-89. DOI: 10.1016/j. det.2014.09.007.

4. Bae JM, Jung HM, Hong BY, Lee JH, Choi WJ, Lee JH, et al. Phototherapy for Vitiligo: A Systematic Review and Metaanalysis. JAMA Dermatol. 2017; 153 (7): 666-674. DOI: 10.1001/ jamadermatol.2017.0002.

5. Chaowattanapanit S, Choonhakarn C, Foocharoen C, Julanon N

Phototherapy in systemic sclerosis: Review. Photodermatol Photoimmunol Photomed. 2017; 33 (6): 296-305. DOI: 10.1111/ phpp.12331.

6. Guitart J. Psoralen Plus UV-A Therapy in the 21st Century: Use It or Lose It. JAMA Dermatol. 2019; 155 (5): 529-31. DOI: 10.1001/ jamadermatol.2018.5844.

7. Richard EG. The Science and (Lost) Art of Psoralen Plus UVA Phototherapy. Dermatol Clin. 2020; 38 (1): 11-23. DOI: 10.1016/j. det.2019.08.002.

8. Vieyra-Garcia PA, Wolf P. Extracorporeal Photopheresis: A Case of Immunotherapy Ahead of Its Time. Transfus Med Hemother. 2020; 47 (3): 226-35. DOI: 10.1159/000508479.

9. Torres AE, Lyons AB, Hamzavi IH, Lim HW. Role of phototherapy in the era of biologics. J Am Acad Dermatol. 2020; S0190-9622 (20): 30711-8. DOI: 10.1016/j.jaad.2020.04.09. 
10. Potapenko AYa, Kyagova AA, Bezdetnaya LN, Lysenko EP, Chernyakhovskaya IYu, Bekhalo VA, et al. Products of psoralen photooxidation possess immunomodulative and antileukemic effects. Photochem Photobiol. 1994; 60 (2): 171-4. DOI: 10.1111/j.1751-1097.1994.tb05086.x.

11. Пятницкий И. А., Павлова С. И., Албегова Д. З., Козлов И. Г., Потапенко А. Я., Кягова А. А. Супрессорное действие продуктов фотоокисления псоралена на реакцию контактной чувствительности у мышей: ингибирование пролиферации и индукция апоптоза лимфоцитов. Российский журнал кожных и венерических болезней. 2013; 6: 59-63.

12. Honda T, Egawa G, Grabbe S, Kabashima K. Update of immune events in the murine contact hypersensitivity model: toward the understanding of allergic contact dermatitis. J Invest Dermatol. 2013; 133 (2): 303-15. DOI: 10.1038/jid.2012.284.

13. Caffieri S. Furocoumarin photolysis: chemical and biological aspects. Photochem Photobiol Sci. 2002; 1 (3): 149-57. DOI: 10.1039/b107329j.

14. Potapenko AYa, Malakhov MV, Kyagova AA. Photobiophysics of furocoumarins. Biophysics. 2004; 49 (2): 307-24.

15. Marley KA, Larson RA, Davenport R. Alternative mechanisms of psoralen phototoxicity. ACS Symposium Series. 1995; 616 (15): 179-88. DOI: 10.1021/bk-1995-0616.ch015.

16. Caffieri S, Di Lisa F, Bolesani F, Facco M, Semenzato G, Dall'Acqua F et al. The mitochondrial effects of novel apoptogenic molecules generated by psoralen photolysis as a crucial mechanism in PUVA therapy. Blood. 2007; 109 (11): 4988-94. DOI: 10.1182/ blood-2006-08-037192.

17. Viola G, Salvador A, Vedaldi D, Dall'Acqua F, Bianchi N, Zuccato C, et al. Differentiation and apoptosis in UVA-irradiated cells treated with furocoumarin derivatives. Ann NY Acad Sci. 2009; 1171: 334-44. DOI: 10.1111/j.1749-6632.2009.04894.x.

18. Филимонов Д. А., Лагунин А. А., Глориозова Т. А., Рудик А. В., Дружиловский Д. С., Погодин П. В. и др. Предсказание спектров биологической активности органических соединений используя веб-ресурс PASS Online. Химия гетероциклических соединений. 2014; 50 (3): 483-99. DOI: 10.1007/s10593-014-1496-1.

19. Филимонов Д. А., Дружиловский Д. С., Лагунин А. А., Глориозова Т. А., Рудик А. В. и др. Компьютерное прогнозирование спектров биологической активности химических соединений: возможности и ограничения. Biomedical Chemistry: Research and Methods. 2018; 1 (1): e00004. DOI: 10.18097/BMCRM00004.

20. Filimonov D, Poroikov V, Borodina Yu, Gloriozova T. Chemical Similarity Assessment through Multilevel Neighborhoods of Atoms: Definition and Comparison with the Other Descriptors. J Chem Inf Comput Sci. 1999; 39 (4): 666-70. DOI: 10.1021/ ci980335o.
21. Lagunin AA, Goel RK, Gawande DY, Pahwa P, Gloriozova TA, Dmitriev AV, et al. Chemo- and bioinformatics resources for in silico drug discovery from medicinal plants beyond their traditional use: a critical review. Nat Prod Rep. 2014; 31 (11): 1585-611. DOI: 10.1039/c4np00068d.

22. Kim S, Chen J, Cheng T, Gindulyte A, He J, He S, et al. PubChem 2019 update: improved access to chemical data. Nucleic Acids Res. 2019; 47 (D1): D1102-9. DOI: 10.1093/nar/gky1033.

23. Willett $P$. Similarity-based virtual screening using $2 \mathrm{D}$ fingerprints. Drug Discov Today. 2006; 11 (23-24): 1046-53.

24. Chen H, Hall S, Zheng B, Rhodes J. Potentiation of the Immune System by Schiff Base-Forming Drugs. BioDrugs. 1997; 7 (3): 217-31. DOI: 10.2165/00063030-199707030-00005.

25. Kyagova AA, Mansurova GV, Kozir LA, Ponomarev GV, Pavlov VY, Konstantinov IO, et al. Systemic suppression of the contact hypersensitivity by the products of protoporphyrin IX photooxidation. Photochem Photobiol. 2005; 81 (6): 1380-5. DOI: 10.1562/2005-04-26-RA-500.

26. Nevezhin EV, Vlasova NV, Pyatnitskiy IA, Lysenko EP, Malakhov MV On the mechanism of erythrocyte hemolysis induced by photooxidized psoralen. Biochemistry (Moscow). 2015; 80 (6): 763-8. DOI: 10.1134/S0006297915060115

27. Yin C, Huo F, Zhang J, Martínez-Máñez R, Yang $Y, L v H$, et al Thiol-addition reactions and their applications in thiol recognition. Chem Soc Rev. 2013; 42 (14): 6032-59. DOl: 10.1039/c3cs60055f.

28. Patil SA, Prabhakara CT, Halasangi BM, Toragalmath SS, Badami PS. DNA cleavage, antibacterial, antifungal and anthelmintic studies of $\mathrm{Co}(\mathrm{II}), \mathrm{Ni}(\mathrm{II})$ and $\mathrm{Cu}(\mathrm{II})$ complexes of coumarin Schiff bases: synthesis and spectral approach. Spectrochim Acta A Mol Biomol Spectrosc. 2015; 137: 641-51. DOI: 10.1016/i.saa.2014.08.028.

29. Marzaro F, Lampronti I, Borgatti M, Manzini P, Gambari R, Chilin A. Psoralen derivatives as inhibitors of NF kB DNA interaction - the critical role of the furan ring. Mol Divers. 2015; 19 (3): 551-61. DOI: 10.1007/s11030-015-9586-2.

30. Smith AC, Yardley V, Rhodes J, Croft SL. Activity of the novel immunomodulatory compound tucaresol against experimental visceral leishmaniasis. Antimicrob Agents Chemother. 2000; 44 (6): 1494-8. DOI: 10.1128/aac.44.6.1494-1498.2000.

31. Arya R, Rolan PE, Wootton R, Posner J, Bellingham AJ. Tucaresol increases oxygen affinity and reduces haemolysis in subjects with sickle cell anaemia. Br J Haematol. 1996; 93 (4): 817-21. DOI: 10.1046/j.1365-2141.1996.d01-1744.x.

32. Sova M. Antioxidant and antimicrobial activities of cinnamic acid derivatives. Mini Rev Med Chem. 2012; 12 (8): 749-67. DOI: 10.2174/138955712801264792.

33. Zaric BL, Obradovic M, Bajic V, Haidara MA, Jovanovic M, Isenovic ER. Homocysteine and Hyperhomocysteinaemia. Curr Med Chem. 2019; 26 (16): 2948-61. DOI: 10.2174/092986732 5666180313105949 